\title{
Study On Popular Culture Contacts and Traditional Cultural Identity in the Youth Group
}

\author{
Hu Yang
}

Chongqing City Management College, Chongqing, 401331

Keywords: popular culture; youth group; cultural identity

\begin{abstract}
With the deepening of globalization as well as the further development of information society, the youth group are undergoing impacts from constantly changing popular culture. From aspects of fashion clothing culture, cyberculture, film and television culture, music culture and festival culture, which are familiar to the youth group, the article analyses the influence exerted by popular culture on traditional cultural identity in the youth group, and this will provide a perspective of experience when it comes to reinforce a sense of identity and confidence among the youth group in traditional culture.
\end{abstract}

\section{Introduction}

With further development of information technology and deepening of globalization, the earth is becoming a global village. Cultural communication, breaking through former regional limitations as cultural barriers have been broken down, runs smoothly throughout the world. This trend, on the one hand, enables a nation to lift territorial restriction and be integrated into other parts of the world, makes the nation be in the fast track of economic development, and boosts its own economic and social development. On the other hand, globalization and modern social transformation accelerate the flow of population, and mutual influences of all kinds of cultures destroy autonomous space for a nation's original culture. Totally different cultures of various origins blend into the current of cultural communication, making it hard for members in it to establish stable cultural characteristics and unique connotations, which challenges the independency of a nation's traditional culture.

Being at the cutting edge of the entire social culture, popular culture also changes rapidly when different cultures meet and integrate. In addition, as the socialization of media continuously permeates through members in the society, popular culture greatly influences their mindsets and behavior patterns. The youth group, with an instinct of sensing the coming of popular culture, are active practitioners and carriers. In this regard, through empirical research on this group exposed to popular culture, the article explores a series of issues such as the exact impact this exposure to popular culture has on traditional cultural identity of the young, and if it does have certain influence, then which form of popular culture influences the most and so on, offering a perspective of experience when it comes to reinforce a sense of identity and confidence among the youth group in traditional culture.

\section{Research method}

Cultural identity is the feeling of belonging to a group and the recognition to a certain society or a nation's traditional culture. It is commonly divided into three levels: cultural cognition, cultural 
emotion and behavioral intentions. When designing questionnaires about cultural identity, the article also takes these three factors into consideration and operates on them separately. The article chooses five major genres of popular culture (fashion clothing culture, cyber culture, film and television culture, music culture and festival culture) to examine its influence on the youth group.

The questionnaire consists of three sectors: basic information, cultural identity and popular culture. Moreover, both sectors of cultural identity and popular culture have different questions according to different levels and genres mentioned above, and each level and genre have 5-8 corresponding questions required to answer on 5-point Likert scale.

The existing study suggests that cultural identity, which stems from history and culture, closely relates to current social culture context and is influenced by emotional personality ofan individual itself and demands for interest, is a dynamic process and an integrated atmosphere which different constructing resources connect, interact and form in certain historical periods and regions. Thus, the article assumes that the exposure to popular culture has a positive influence on the youth group.

Based on the practical situation in china and considering opportunities and degrees the youth group have to be exposed in popular culture, the respondents picked out by stratified random sampling are college students of the 90's from all four grades in a university in Chongqing, 550 in total. There are 519 valid questionnaires after eliminating 31 invalid ones. Among the valid questionnaires, there are 232 males and 287 females, with an average age of 19.5.

\section{Research Findings}

The youth group get to know popular and traditional culture mainly from the internet plus film and television. But there is a slight difference between the two. The channels for popular culture, in turn, are the internet, film and television, communication between peers, newspapers and so on, while those for traditional culture are the internet, film and television, textbooks, newspapers and others. It can be obviously seen that origins of traditional culture are related more to education in school and are also bound up with home education.

As for fashion clothing culture, people tend to believe traditional clothing makes people better understand features of their unique culture, at 78.8 percent; and in the light of granny chic and folk style clothing wide spread, most respondents think this trend can popularize national culture and make more people interested in traditional clothing culture.

In the aspect of cyber culture, 54.1 percent of people are fond of all kinds of web novels on adventure, fantasy, sword and sorcery etc. and believe that web fictions deepen the understanding and affection for traditional Chinese culture.

In terms of film and television culture, TV series and variety shows have gone virus, especially among the youth group, with about half of them saying variety shows like Where are we going, Dad profoundly help understand traditional family culture and ways to express feelings between parents and their children.

In current music culture, many pop singers are recomposing traditional Chinese music, such as folk music of all ethnics and Huayin Old Opera. 63.9 percent of respondents believe this trend enriches their understandings of traditional Chinese opera and Chinese Classical Play. 
Table 1 Analysis of Influence on Cultural Cognition from Popular Culture

\begin{tabular}{|c|c|c|c|c|c|}
\hline Categories & $\begin{array}{l}\text { Strongly } \\
\text { Agree }\end{array}$ & Agree & Indifferent & Disagree & $\begin{array}{l}\text { Strongly } \\
\text { Disagree }\end{array}$ \\
\hline $\begin{array}{l}\text { Traditional clothing of all ethnics is a } \\
\text { status symbol and can make itself better } \\
\text { understood }\end{array}$ & $28.3 \%$ & $50.5 \%$ & $14.8 \%$ & $5.8 \%$ & $0.6 \%$ \\
\hline $\begin{array}{l}\text { Putting Chinese elements can popularize } \\
\text { traditional Chinese culture }\end{array}$ & $36.7 \%$ & $45.0 \%$ & $14.7 \%$ & $3.0 \%$ & $0.6 \%$ \\
\hline $\begin{array}{l}\text { Buzzwords add to understandings of } \\
\text { Chinese culture }\end{array}$ & $10.2 \%$ & $14.5 \%$ & $38.5 \%$ & $20.5 \%$ & $16.3 \%$ \\
\hline $\begin{array}{l}\text { Web novels deepen understandings of } \\
\text { traditional Chinese culture }\end{array}$ & $12.7 \%$ & $40.6 \%$ & $24.9 \%$ & $18.1 \%$ & $3.7 \%$ \\
\hline $\begin{array}{l}\text { Variety shows like Where are we going, } \\
\text { Dad help gain understandings of } \\
\text { traditional family culture in China }\end{array}$ & $18.5 \%$ & $36.0 \%$ & $24.7 \%$ & $15.8 \%$ & $5.0 \%$ \\
\hline $\begin{array}{l}\text { Recomposed traditional folk music } \\
\text { provides far better understandings of } \\
\text { traditional music }\end{array}$ & $17.3 \%$ & $46.6 \%$ & $27.8 \%$ & $7.5 \%$ & $0.8 \%$ \\
\hline $\begin{array}{l}\text { Be quite familiar with both traditional } \\
\text { Chinese festivals and origins }\end{array}$ & $19.1 \%$ & $47.0 \%$ & $30.6 \%$ & $2.7 \%$ & $0.6 \%$ \\
\hline
\end{tabular}

In clothing culture, the youth group have a strong sense of identity in traditional clothing, and 76.3 percent of them express their loving for Tang suits, cheongsam and other traditional Chinese clothing. In addition, about eighty percent of the young find it wonderful that top brands worldwide add Chinese elements to their designs and make suits in folk style, with 35.8 percent of them feeling extremely proud and 43.2 percent feeling proud. Seeing from the data, it is clear that the combination of pop and tradition is recognized and loved by the youth group.

In terms of the statistics, cyber culture has a negative influence on traditional cultural identity compared to other kinds of popular cultures. Unlike web novels, only one fifth of people believe buzzwords deepen the emotional identity of traditional Chinese culture (20.4\%), while 38.5 percent of them say buzzwords make no difference and 32.6 percent of them even think buzzwords destroy the sense of identity in traditional culture. So are things like spoofs on the internet, according to most respondents.

In the aspect of film and television culture, influences exerted by overseas film and television productions should not be neglected. Though the youth group hold a belief that the introduce of these productions in large amounts will have effects on the sense of identity in traditional Chinese culture, the young are fascinated by foreign culture. The percentage of people who think foreign culture displayed in overseas film and television productions is more attractive than Chinese culture is 41.7 , with 10.6 percent strongly agree and 31.1 percent agree.

As for festival culture, traditional festivals are central to the youth group. The percentage of people who believe traditional Chinese festivals are of greater importance than foreign ones is 82.7\%, with 45.7 percent strongly agree and 37 percent agree. Moreover, 21.2 percent of people strongly agree and 56.5 percent of them agree that the prevalence of foreign festivals will affect traditional Chinese festivals. 
Table 2 Analysis on traditional cultural identity

\begin{tabular}{|c|c|c|c|c|c|}
\hline Categories & $\begin{array}{c}\text { Strongly } \\
\text { like/dislike }\end{array}$ & Like/Agree & Indifferent & Dislike/Disagree & $\begin{array}{c}\text { Strongly } \\
\text { dislike/disagree }\end{array}$ \\
\hline $\begin{array}{l}\text { Top brands design clothing with } \\
\text { traditional Chinese elements }\end{array}$ & $35.8 \%$ & $43.2 \%$ & $17.7 \%$ & $3.1 \%$ & $0.2 \%$ \\
\hline $\begin{array}{l}\text { Online spoofs on traditional } \\
\text { classics }\end{array}$ & $22.5 \%$ & $43.4 \%$ & $18.9 \%$ & $12.0 \%$ & $3.3 \%$ \\
\hline $\begin{array}{l}\text { Foreign cultures displayed on } \\
\text { screens are more fascinating than } \\
\text { Chinese culture }\end{array}$ & $10.6 \%$ & $31.1 \%$ & $25.3 \%$ & $23.7 \%$ & $9.3 \%$ \\
\hline $\begin{array}{l}\text { The introduce of TV productions in } \\
\text { large amounts will affect the sense } \\
\text { of identity in traditional Chinese } \\
\text { culture }\end{array}$ & $13.7 \%$ & $38.6 \%$ & $22.5 \%$ & $17.9 \%$ & $7.3 \%$ \\
\hline $\begin{array}{l}\text { Whether like pop music blended } \\
\text { with traditional Chinese elements } \\
\text { or not }\end{array}$ & $30.8 \%$ & $44.7 \%$ & $19.9 \%$ & $3.9 \%$ & $0.8 \%$ \\
\hline $\begin{array}{l}\text { Traditional Chinese festivals are } \\
\text { more important than foreign } \\
\text { festivals }\end{array}$ & $45.7 \%$ & $37.0 \%$ & $13.9 \%$ & $2.5 \%$ & $1.0 \%$ \\
\hline $\begin{array}{l}\text { The prevalence of foreign festivals } \\
\text { will influence traditional Chinese } \\
\text { festivals }\end{array}$ & $21.2 \%$ & $56.5 \%$ & $15.6 \%$ & $4.6 \%$ & $2.1 \%$ \\
\hline
\end{tabular}

In fashion clothing culture, 68 percent of people indicate that they would like to wear folk style clothing. In terms of cyber culture, 78 percent of people agree to use the internet to boost the communication of traditional Chinese culture, with 30.8 percent and 47.2 percent separately. In addition, 72.8 percent of the respondents think cyber culture is supposed to highlight traditional Chinese culture. However, when it comes to festivals, most respondents say that they are more willing to have traditional Chinese festivals rather than foreign festivals, (42.2 percent and 43.7 separately). Meanwhile, almost all people (85.4\%) wish to observe rituals and rites related to certain festival, like the reunion in the Spring festival, holding a memorial ceremony for ancestors and eating traditional Chinese rice-pudding and Moon cake in the Dragon Boat Festival and the Mid-Autumn Festival.

Table 3 Analysis on behavioral intentions on traditional culture

\begin{tabular}{|c|c|c|c|c|c|}
\hline Categories & $\begin{array}{c}\text { Strongly } \\
\text { Agree }\end{array}$ & Agree & Indifferent & Disagree & $\begin{array}{l}\text { Strongly } \\
\text { Disagree }\end{array}$ \\
\hline Willing to wear folk style clothing & $25.2 \%$ & $42.8 \%$ & $25.8 \%$ & $5.4 \%$ & $0.8 \%$ \\
\hline $\begin{array}{c}\text { Using the internet to boost the } \\
\text { communication of traditional Chinese } \\
\text { culture }\end{array}$ & $30.8 \%$ & $47.2 \%$ & $16.4 \%$ & $4.2 \%$ & $1.4 \%$ \\
\hline $\begin{array}{l}\text { More willing to have traditional Chinese } \\
\text { festivals rather than foreign festivals }\end{array}$ & $42.2 \%$ & $42.7 \%$ & $10.8 \%$ & $3.3 \%$ & $1.0 \%$ \\
\hline $\begin{array}{l}\text { More willing to observe the rituals and } \\
\text { rites in traditional festivals }\end{array}$ & $46.4 \%$ & $38.9 \%$ & $11.2 \%$ & $2.3 \%$ & $1.2 \%$ \\
\hline
\end{tabular}




\section{Conclusion and Discussion}

To sum up, actual survey data have supported the hypothesis that popular culture contacts in fashion clothing culture, film and television culture, music culture and festival culture have positive influences on traditional cultural identity among the youth group. This increases the awareness of traditional culture, strengthens the emotional identity and further boosts behavioral intentions of popularizing traditional culture by the youth group. But the statistics also show that cyber culture have negative effects on traditional cultural cognition among them, and foreign film and television productions as well as foreign festivals has no positive effects neither.

Firstly, not all cyber culture contacts have positive influences on traditional cultural cognition among the youth group. According to the statistics, web fictions, apparently, have positive effects upon traditional cultural identity among the youth group. Objectively speaking, besides literary values of web novels, readers can get the hang of traditional Chinese culture from these works more or less, and thus help gain cultural cognition and the sense of emotional identification. However, when it comes to buzzwords, spoofs and other cyber culture, most young people consider it quite negative to make traditional culture recognized (supportive statistics are mentioned above). The youth group are main producers, users and carriers. When they accept passive information hidden behind buzzwords and spoofs, which features as decomposing mainstream cultures and diminishing traditional authority, the youth group will fail to resonate with traditional culture. As a result, how to intensify characteristics of traditional cultures on the internet as a way to increase the sense of identity in traditional culture among the youth group is an urgent issue confronting us all.

Besides, the negative influence of foreign film and television culture on traditional cultural identity among the youth group is growing obvious. With the deepening of globalization and widening of marketization, screens of all kinds of devices available to the young are overcrowded with various kinds of overseas film and television productions and variety shows. As is showed before, young people exposed to foreign film and television culture tend to be attracted by foreign culture and even think that foreign culture is superior to ours, which is detrimental to the establishment of traditional cultural identity. We are facing a problem of how to curb this trend and lead young people to see foreign culture correctly without triggering rebellious attitudes. In this way, the sense of identity and confidence among the youth group in traditional culture can be reinforced.

Lastly, the popularity of foreign festivals exerts negative influences on traditional cultural cognition among the youth group. It can be seen from the data that most respondents believe the gradual prevalence of festivals from other parts of the world do have impacts on traditional Chinese culture. Actually, these festivals target at consuming social culture. Young people are vulnerable to propagandas and incitement both physically and mentally, which is the trick of businesses to gain more profits. So, the youth group regard celebrating foreign festivals as a symbol of good taste and high social status, and even ignore traditional Chinese festivals since they are obsolete, and consequently, the sense of traditional cultural identity is diminished.

\section{About the author}

$\mathrm{Hu}$ Yang, PhD in educational technology at Southwest University, lecturer in Chongqing City Management College, focusing on media education and new media communication. E-mail: 15949327@qq.com. Telephone: 02365360256. 


\section{References}

[1] Wu shi wen, Shi yi shan. Media contact of Chinese and Chinese cultural identity ---- An empirical study of Wuhan City[J]. Jouralism and Communication Studies. 2014, 1, pp. 14-19.

[2] Anthony Smith. Nationalism and nationalism in the era of Globalization[M]. Beijing. Central Compilation Press. 2002, p.17.

[3] Shi yi shan, Xiong hui, Peng biao. An analysis of the history and current situation of the development of cultural identity[R]. China Media Development Report(2007). Wuhan. Wuhan University Press. 2007.

[4] China Youth Research Center, New media and youth culture research center of Soochow University. The characteristics of youth culture in the new media space----A report on the research of youth network popular culture[J]. Chinese Youth Studies. 2016, 7, pp. 144-49.

[5] Cai qi. Reflection on the Network KUSO culture[J]. International Press. 2007, 1, pp. 182-188.

[6] Baudrillard. Consumer society[M]. Translate by Liu cheng fu. Nanjing. Nanjing University Press. 2006. 